\title{
ESENSI PERLINDUNGAN HUKUM DALAM SISTEM FIRST TO ANNOUNCE ATAS KARYA CIPTA
}

\author{
Siti Hatikasari \\ Fakultas Hukum, Universitas Indonesia \\ sitihatikasari@gmail.com / siti.hatikasari@ui.ac.id
}

\begin{abstract}
This research aims to study and to analyze the essence of copyright legal protection for a copyrighted work in first to announce system based on Copyright law in Indonesia. This research is a normative legal research using a statutory approach. Therefore, copyrighted works protected is copyrighted works that have become the personal property, thus it is prohibited from copying copyrighted works or using works without the permission from copyright owner. Then, announced copyrighted works in principle do not have to be registered, but one of copyright legal protection besides first to announce is copyright registration.
\end{abstract}

Keywords : Copyright; Legal Protection; First To Announce.

\begin{abstract}
Abstrak
Penulisan ini bertujuan untuk mengkaji dan menganalisis esensi dari perlindungan hukum hak cipta atas sebuah karya cipta dalam sistem first to announce berdasarkan undang-undang Hak Cipta yang berlaku di Indonesia. Penelitian ini merupakan penelitian hukum normatif yang menggunakan pendekatan perundang-undangan. Demikian dalam penelitian ini ditemukan bahwa karya cipta yang dapat dilindungi yaitu karya cipta yang telah menjadi hak milik pribadi seseorang, sehingga dilarang melakukan penggandaan karya cipta atau menggunakan karya tanpa seizin Pemilik Pemegang Hak Cipta. Kemudian karya cipta yang telah diumumkan pada prinsipnya tidak harus dilakukan pendaftaran atau pencatatan, namun salah satu bentuk perlindungan hukum hak cipta selain pengumuman pertama kali tersebut adalah dapat ditambahkan dengan pendaftaran hak cipta.
\end{abstract}

Kata Kunci : Hak Cipta; Perlindungan Hukum; First To Announce.

\section{PENDAHULUAN}

Pesatnya perkembangan globalisasi telah mendukung perubahan dari berbagai segi kehidupan, salah satunya pertumbuhan ekonomi yang bergerak cepat dan dinamis. Perubahan ini mendorong masyarakat untuk terus berinovasi dan berpikir secara kreatif agar dapat bertahan dalam suatu persaingan di bidang ekonomi. Namun tidak semua masyarakat memiliki tujuan yang sama dalam menciptakan persaingan yang sehat, karena masih banyaknya ditemukan berbagai pelanggaran khususnya dalam hal kreativitas yang memicu permasalahan dalam masyarakat. Selanjutnya dengan perkembangan ilmu pengetahuan, teknologi, seni dan sastra, sudah demikian pesat sehingga memerlukan peningkatan perlindungan dan jaminan

Siti Hatikasari, Esensi Perlindungan Hukum Dalam Sistem First To Announce Atas Karya Cipta 
kepastian hukum bagi pencipa, pemegang Hak Cipta dan pemilik Hak Terkait, ${ }^{1}$ namun tentunya dengan tetap memperhatikan kepentingan publik. Penegakan hukum atas hak cipta dilakukan oleh pemegang hak cipta dalam ranah hukum perdata. Meskipun demikian, penegakan hukum atas hak cipta juga dapat melalui pendekantan ranah hukum pidana ${ }^{2}$, maupun ranah hukum administrasi.

Pada dasarnya, pelanggaran hak cipta terjadi apabila materi hak cipta tersebut digunakan tanpa izin dan harus ada kesamaan antara dua karya yang ada ${ }^{3}$. Hak cipta merupakan bagian dari Hak Kekayaan Intelektual. Suatu karya intelektual yang mendapat perlindungan hak cipta apabila telah diwujudkan sebagai ciptaan yang berwujud atau berupa ekspresi yang dapat dilihat, didengar dan dibaca, ${ }^{4}$ hal ini sama seperti perlindungan hak cipta yang diatur dalam undang-undang Hak Cipta di Indonesia. Undang-undang Hak Cipta tidak melindungi suatu ide atau gagasan seseorang yang bersifat abstrak, melainkan yang diakui dan memperoleh perlindungan hak cipta adalah hasil ekspresi dari ide atau gagasan dalam wujud karya cipta bersifat materil. 5

Hak cipta adalah hak eksklusif pencipta yang timbul secara otomatis berdasarkan prinsip deklaratif setelah suatu ciptaan diwujudkan dalam bentuk nyata tanpa mengurangi pembatasan sesuai dengan ketentuan peraturan perundangundangan ${ }^{6}$. Hak cipta terdiri atas hak ekonomi (economic rights) dan hak moral (moral rights). Hak ekonomi adalah hak untuk mendapatkan manfaat ekonomi atas ciptaan serta produk terkait. Hak moral adalah hak yang melekat pada diri pencipta atau pelaku yang tidak dapat dihilangkan atau dihapus dengan alasan apapun walaupun hak cipta atau hak terkait tersebut telah dialihkan.

Berdasarkan ketentuan yang ada, pencipta diberikan hak ekonomi berupa hak mengumumkan (performing rights) dan hak untuk memperbanyak (mechanical rights).

1Laina Rafianti, Resensi Buku: Sejarah dan Politik Hukum Hak Cipta. Jurnal Bina Mulia Hukum, 2(2), 266-273, 2018. doi : 10.23920/jbmh.v2n2.21. p.269-270

2 Oksidelfa Yanto, Konsep Perlindungan hak Cipta Karya Musik Dalam ranah Hukium Hak Kekayaan Intelektual dari Tindak Pidana Pembajakan. Jurnal Cita Hukum, 3(1), 99-114, 2015. doi: 10.15408/JCH.v2i1.2310.2015.3.1.p.100

3 Endang Purwaningsih, Perkembangan Hukum Intellectual Property Rights, Jakarta: Ghalia Indonesia, 2005, hlm. 6

4 Kadek Julia Mahadewi, Budaya Hukum Dalam Keberlakuan UndangUndang Nomor 28 Tahun 2014 Tentang Hak Cipta Pada Pengrajin Perak di Bali. Jurnal Magister Hukum Udayana, 4 (2), 205-218, 2015. doi: 10.24843/JMHU.2015.v04.i02.p.206

5 Hendra Djaja, Hukum Hak Kekayaan Intelektual, Malang: Surya Pena Gemilang, 2010, hlm. 159

6 Republik Indonesia, Undang-Undang Nomor 28 Tahun 2014 tentang Hak Cipta, Lembaran Negara Republik Indonesia (LNRI) Tahun 2014 Nomor 266, dan Tambahan Lembaran Negara (TLM) Nomor 5599, Pasal 1 angka 1

Siti Hatikasari, Esensi Perlindungan Hukum Dalam Sistem First To Announce Atas Karya Cipta 
Adapun hak moral meliputi hak pencipta untuk dicantumkan namanya dalam ciptaan dan hak pencipta untuk melarang orang lain mengubah ciptaannya, termasuk judul ataupun anak judul ciptaan ${ }^{7}$. Perlindungan hak cipta adalah sebagai salah satu tujuan dari diterbitkannya seluruh peraturan hukum tentang hak cipta, termasuk konvensi internasional. Di Indonesia, perlindungan hak cipta telah diatur dalam Undang-Undang Nomor 28 Tahun 2014 tentang Hak Cipta yang menggantikan undang-undang yang lama yaitu Undang-Undang Nomor 19 Tahun 2002 tentang Hak Cipta. Konsep hak cipta di Indonesia, merupakan terjemahan dari konsep copyright dalam bahasa Inggris. Konvensi Berne pada tahun 1886 adalah yang pertama kali mengatur masalah copyright antar negara yang berdaulat. Dalam konvensi ini, copyright diberikan secara otomatis kepada karya kreatif, dan pengarang tidak harus mendaftarkan karyanya untuk mendapatkan copyright. Segera setelah sebuah karya dicetak atau disimpan dalam satu media, pengarang otomatis mendapatkan hak eksklusif copyright terhadap karya tersebut, dan juga terhadap karya derivatif hingga pengarang secara eksplisit menyatakan sebaliknya atau hingga masa berlaku copyright tersebut selesai8.

Pada tahun 1958, Perdana Menteri Djuanda menyatakan Indonesia keluar dari Konvensi Berne agar para intelektual Indonesia bisa memanfaatkan hasil karya, cipta dan karsa bangsa asing, tanpa harus membayar royalti. Tahun 1982, Pemerintah Indonesia mencabut pengaturan tentang hak cipta berdasarkan Auteurswet 1912 Staatsblad Nomor 600 tahun 1912 dan menetapkan Undang-Undang Nomor 6 Tahun 1982 tentang Hak Cipta, yang merupakan Undang-Undang Hak Cipta yang pertama di Indonesia. Undang-undang tersebut kemudian diubah dengan Undang-undang Nomor 7 Tahun 1987, Undang-undang Nomor 12 Tahun 1997, Undang-undang Nomor 19 Tahun 2002, dan pada akhirnya Undang-Undang Nomor 28 Tahun 2014 (selanjutnya disebut dengan UUHC) yang saat ini masih berlaku.

Perlindungan hak cipta berfungsi untuk melindungi hak-hak yang dimiliki oleh pencipta atas karya ciptaannya, hak cipta melindungi juga potensi pencipta karena eksistensi terhadap kemampuan yang dimiliki seorang pencipta untuk menciptakan suatu karya cipta dan karya ciptaannya tetap terjaga. Salah satu bentuk perlindungan hukum terhadap hak kekayaan intelektual yaitu dengan cara mendaftarkannya. Tidak seperti paten dan merek, pendaftaran karya cipta memang tidak wajib karena perlindungan hukum atas karya cipta itu otomatis berlaku pada saat pertama kali diumumkan kepada publik. Namun hal ini kerap menjadi masalah dalam prakteknya, salah satu contoh kasusnya adalah kasus pembatalan

7 Henry Soelistyo, Hak Cipta Tanpa Hak Moral, Jakarta: PT. Raja Grafindo Persada, 2011, hlm. 47

8 Aryani Nauli Hasibuan, Perlindungan Hak Cipta Atas Karya Derivatif dalam Prakteknya: Studi Kasus Buku Ensiklopedia Al-Quran: Al-Maushuah Al-Quraniyah AlMuyassarah, dalam Tesis Fakultas Hukum Universitas Indonesia, 2011, hlm. 6

Siti Hatikasari, Esensi Perlindungan Hukum Dalam Sistem First To Announce Atas Karya Cipta 
pendaftaran ciptaan seni lukis motif abstrak yang berbentuk kepala orang dengan judul "Diesel Only The Brave".

Berdasarkan latar belakang di atas, maka ada dua rumusan masalah yang dikaji penulis dalam penelitian ini yaitu pertama mengenai perlindungan hukum hak cipta atas sebuah karya cipta di Indonesia berdasarkan Undang-Undang Nomor 28 Tahun 2014 tentang Hak Cipta, dan kedua, terkait esensi perlindungan hukum dalam sistem first to announce yang dikaitkan dengan Putusan Nomor: 08/Pdt.Sus-Hak Cipta/2016/PN.Niaga.Jkt.Pst tentang pembatalan pendaftaran suatu ciptaan.

Berdasarkan rumusan masalah yang diuraikan di atas, maka tujuan peneliti dalam penelitian ini yaitu untuk mengkaji dan menganalisis esensi dari perlindungan hukum hak cipta atas sebuah karya cipta dalam sistem first to announce yang dikaitkan dalam kasus dengan Putusan Nomor: 08/Pdt.Sus-Hak Cipta/2016/PN.Niaga.Jkt.Pst terkait pembatalan pendaftaran suatu ciptaan, berdasarkan undang-undang Hak Cipta yang berlaku di Indonesia.

\section{METODE PENELITIAN}

Dalam penelitian ini menggunakan metode penelitian hukum normatif. Dengan kata lain, penelitian hukum yang dilakukan dengan meneliti bahan pustaka atau data sekunder belaka. ${ }^{9}$ Dalam penelitian hukum normatif ini menggunakan pendekatan perundang-undangan (statute approach), hal ini dilakukan dengan menelaah undangundang dan/atau regulasi yang terkait dengan isu hukum yang sedang ditangani. 10 Adapun bahan dasar penelitian hukum normatif ini yakni bahan hukum primer, bahan hukum sekunder dan bahan hukum tersier atau penunjang. ${ }^{11}$ Setelah dilakukan pengumpulan bahan hukum tersebut, berikutnya penulis melakukan analisis dan pengkajian.

\section{HASIL DAN PEMBAHASAN}

Perlindungan Hukum Hak Cipta di Indonesia Berdasarkan Undang-Undang Nomor 28 Tahun 2014 tentang Hak Cipta

Perlindungan hukum adalah suatu perlindungan yang diberikan terhadap subjek-subjek hukum melalui Peraturan Perundang-undangan yang berlaku dan dalam pelaksanaannya terdapat suatu sanksi, dalam bentuk perangkat hukum baik yang bersifat preventif maupun yang bersifat represif, baik yang tertulis maupun tidak tertulis. Sehingga perlindungan hukum dapat disebut sebagai suatu gambaran dari fungsi hukum, yaitu konsep dimana hukum dapat mem ketertiban, kepastian, kemanfaatan dan kedamaian.

9 Soerjono Soekanto, Sri Mamudji. Penelitian Hukum Normatif. Jakarta: PT. Raja Grafindo Persada, 2012. hlm. 13.

10 Ibid,.hlm. 11.

11 Ibid, hlm. 38.

Siti Hatikasari, Esensi Perlindungan Hukum Dalam Sistem First To Announce Atas Karya Cipta 
Perlindungan hukum preventif merupakan perlindungan yang diberikan oleh pemerintah dengan tujuan untuk mencegah sebelum terjadinya pelanggaran. Hal ini terdapat dalam peraturan perundang-undangan dengan maksud untuk mencegah suatu pelanggaran serta memberi rambu-rambu atau batasan-batasan dalam melakukan suatu kewajiban. Dengan adanya aturan tersebut akan memberikan landasan pada pihak-pihak yang terkait untuk menegakkan apa yang dicita-citakan oleh hukum ${ }^{12}$.

Lahirnya undang-undang Hak Cipta yang baru sebagai bentuk perwujudan perlindungan hukum bagi hak cipta di Indonesia yaitu Undang-Undang Nomor 28 Tahun 2014 tentang Hak Cipta (UUHC) menggantikan undang-undang yang lama yaitu Undang-Undang Nomor 19 Tahun 2002. Pertimbangan lahirnya UUHC yang baru adalah sebagai berikut ${ }^{13}$ :

a. Hak cipta merupakan kekayaan intelektual di bidang ilmu pengetahuan, seni, dan sastra yang mempunyai peranan strategis dalam mendukung pembangunan bangsa dan memajukan kesejahteraan umum sebagaimana diamanatkan oleh UUD Tahun 1945.

b. Perkembangan ilmu pengetahuan, teknologi, seni dan sastra sudah demikian pesat sehingga memerlukan peningkatan perlindungan dan jaminan kepastian hukum bagi pencipta, pemegang Hak Cipta, dan pemilik Hak Terkait.

c. Indonesia telah menjadi anggota berbagai perjanjian internasional di bidang hak cipta dan hak terkait sehingga diperlukan implementasi lebih lanjut dalam sistem hukum nasional agar para pencipta dan kreator nasional mampu berkompetisi secara internasional.

d. UU Nomor 19 Tahun 2002 tentang Hak Cipta sudah tidak sesuai dengan perkembangan hukum dan kebutuhan masyarakat sehingga perlu diganti dengan undang-undang yang baru.

Dalam UUHC Pasal 1 angka 1 disebutkan bahwa hak cipta adalah hak eksklusif pencipta yang timbul secara otomatis berdasarkan prinsip deklaratif setelah suatu ciptaan diwujudkan dalam bentuk nyata tanpa mengurangi pembatasan sesuai dengan ketentuan peraturan perundang-undangan. Berdasarkan ketentuan Pasal 1 ayat (1) UU No. 28 Tahun 2014 tentang Hak Cipta, unsur-unsur yang melekat dari Hak Cipta, yaitu ${ }^{14}$ :

12 Muhammad Riyan Kachfi Boer, Tinjauan Yuridis Tentang Tindak Pidana Terhadap Hak Cipta Atas Perangkat Lunak Komputer (Studi Kasus Putusan Nomor 2277 K/Pid/2006) dalam Skripsi Fakultas Hukum Universtas Hasanuddin, 2015, hlm. 5

13 Republik Indonesia, tentang Hak Cipta, Op. Cit., Pertimbangan

14 M. Hutahuruk, Peraturan Hak Cipta Nasional, Jakarta: Erlangga, 1982, hlm. 11 .

Siti Hatikasari, Esensi Perlindungan Hukum Dalam Sistem First To Announce Atas Karya Cipta 
1. Hak Eksklusif, yang berarti bahwa tidak ada pihak lain yang dibenarkan untuk memanfaatkan hak tersebut tanpa adanya izin dari Pencipta atau Pemegang Hak Cipta.

2. Hak eksklusif tersebut timbul secara otomatis sejak diumumkan (deklaratif), yang menegaskan hak ekonomis dari Hak Cipta.

3. Terdapat batasan-batasan menurut hukum. Hal ini menunjukkan bahwa selain hak eksklusif tersebut, hak cipta juga mempunyai fungsi sosial

Pada UUHC sendiri disebutkan jenis karya cipta yang dilindungi, yaitu karya cipta yang telah menjadi hak milik pribadi seseorang, sehingga dilarang melakukan penggandaan karya cipta atau menggunakan karya tanpa seizin Pemilik atau Pemegang Hak Cipta. Jenis ciptaan yang dilindungi tersebut antara lain ${ }^{15}$ :

1) Ciptaan yang dilindungi meliputi Ciptaan dalam bidang ilmu pengetahuan, seni, dan sastra, terdiri atas:

a. buku, pamflet, perwajahan karya tulis yang diterbitkan, dan semua hasil karya tulis lainnya;

b. ceramah, kuliah, pidato, dan Ciptaan sejenis lainnya;

c. alat peraga yang dibuat untuk kepentingan pendidikan dan ilmu pengetahuan;

d. lagu dan/atau musik dengan atau tanpa teks;

e. drama, drama musikal, tari, koreografi, pewayangan, dan pantomim;

f. karya seni rupa dalam segala bentuk seperti lukisan, gambar, ukiran, kaligrafi, seni pahat, patung, atau kolase;

g. karya seni terapan;

h. karya arsitektur;

i. peta;

j. karya seni batik atau seni motif lain;

k. karya fotografi;

1. Potret;

m. karya sinematografi;

n. terjemahan, tafsir, saduran, bunga rampai, basis data, adaptasi, aransemen, modifikasi dan karya lain dari hasil transformasi;

o. terjemahan, adaptasi, aransemen, transformasi, atau modifikasi ekspresi budaya tradisional;

p. kompilasi Ciptaan atau data, baik dalam format yang dapat dibaca dengan Program Komputer maupun media lainnya;

q. kompilasi ekspresi budaya tradisional selama kompilasi tersebut merupakan karya yang asli;

r. permainan video; dan

15 Republik Indonesia, tentang Hak Cipta, ibid., Pasal 40.

Siti Hatikasari, Esensi Perlindungan Hukum Dalam Sistem First To Announce Atas Karya Cipta 
s. Program Komputer.

2) Ciptaan sebagaimana dimaksud pada ayat (1) huruf $n$ dilindungi sebagai Ciptaan tersendiri dengan tidak mengurangi Hak Cipta atas Ciptaan asli.

3) Pelindungan sebagaimana dimaksud pada ayat (1) dan ayat (2), termasuk pelindungan terhadap Ciptaan yang tidak atau belum dilakukan Pengumuman tetapi sudah diwujudkan dalam bentuk nyata yang memungkinkan Penggandaan Ciptaan tersebut.

Selanjutnya pada Pasal 41 juga disebutkan hasil karya yang tidak dilindungi hak cipta selain hasil karya yang dapat dilindungi hak cipta. Setiap orang bebas dan boleh mengumumkan atau memperbanyak ciptaan tersebut untuk keperluan apa saja karena ciptaan tersebut bukan merupakan ciptaan milik pribadi seseorang.

Ciptaan yang tidak dilindungi tersebut antara lain :

a. hasil karya yang belum diwujudkan dalam bentuk nyata;

b. setiap ide, prosedur, sistem, metode, konsep, prinsip, temuan atau data walaupun telah diungkapkan, dinyatakan, digambarkan, dijelaskan, atau digabungkan dalam sebuah Ciptaan; dan

c. alat, benda, atau produk yang diciptakan hanya untuk menyelesaikan masalah teknis atau yang bentuknya hanya ditujukan untuk kebutuhan fungsional.

Tidak ada Hak Cipta atas hasil karya berupa16:

a. hasil rapat terbuka lembaga negara;

b. peraturan perundang-undangan;

c. pidato kenegaraan atau pidato pejabat pemerintah;

d. putusan pengadilan atau penetapan hakim; dan

e. kitab suci atau simbol keagamaan.

Hak cipta adalah merupakan bagian dari hak milik intelektual yang keberadaannya tidak berwujud dalam arti hak cipta tersebut merupakan penguasaan terhadap hasil dari kemampuan bekerja yang berasal dari gagasan serta hasil pikiran, oleh karena sifatnya yang abstrak tersebut, maka perlindungan terhadap hak cipta ini mempunyai jangka waktu yang terbatas, yaitu setelah habis masa perlindungan hak cipta tersebut maka karya cipta tersebut akan menjadi milik umum.

Pada prinsipnya hak cipta diperoleh bukan karena pendaftaran, jadi tidak ada keharusan bagi Pencipta untuk mendaftarkan ciptaannya seperti disebutkan pada Pasal 64 ayat (2) UUHC bahwa pencatatan bukan syarat untuk mendapatkan Hak Cipta dan Hak Terkait, namun apabila terjadi sengketa di pengadilan mengenai ciptaan yang terdaftar dan yang tidak terdaftar, hakim dapat menentukan pencipta yang sebenarnya berdasarkan pembuktian tersebut. Untuk kepentingan tersebut, maka dipandang perlu untuk melakukan pendaftaran atas ciptaan, terutama

16 Republik Indonesia, tentang Hak Cipta, Ibid., Pasal 42

Siti Hatikasari, Esensi Perlindungan Hukum Dalam Sistem First To Announce Atas Karya Cipta 
mengingat era globalisasi sekarang ini dimana hampir setiap pelaku bisnis berlombalomba memenangkan persaingan. Sehingga pendaftaran atau pencatatan merupakan salah satu bentuk perlindungan hukum hak cipta selain pengumuman pertama kali hasil karya cipta, walaupun pendaftaran hak cipta bukan merupakan suatu keharusan. Pendaftaran diharapkan dapat memberikan semacam kepastian hukum serta lebih memudahkan dalam prosedur pengalihan haknya ${ }^{17}$.

Pendaftaran tidak hanya semata-mata mengandung arti untuk memberikan alat bukti yang kuat, akan tetapi juga menciptakan hak kebendaan. Hak kebendaan atas suatu benda untuk umum terjadi saat pendaftaran itu dilakukan. Selama pendaftaran 9belum terjadi, hak hanya mempunyai arti terhadap para pihak pribadi dan umum dianggap belum "mengetahui" perubahan status hukum atas hak yang dimaksudkan. Pengakuan dari masyarakat baru terjadi pada saat hak tersebut (milik) didaftarkan ${ }^{18}$. Namun pencatatan ciptaan tidak dapat dilakukan terhadap seni lukis yang berupa logo atau tanda pembeda yang digunakan sebagai merek dalam perdagangan barang/jasa atau digunakan sebagai lambang organisasi, badan usaha atau badan hukum sebagaimana disebutkan dalam Pasal 65.

Ada dua jenis cara atau stelsel pendaftaran menurut Prof. Kollewijn yaitu stelsel konstitutif dan stelsel deklaratif. Menurut stelsel konstitutif letak titik berat ada tidaknya hak cipta tergantung pada pendaftarannya. Jika didaftarkan hak cipta itu akan diakui keberadaannya secara de jure dan de facto. Sedangkan stelsel deklaratif titik beratnya diletakkan pada anggapan sebagai pencipta terhadap hak yang didaftarkan itu sampai orang lain dapat membuktikan sebaliknya. Sekalipun hak cipta itu didaftarkan undang-undang hanya mengakui seolah-olah yang bersangkutan sebagai pemiliknya, secara de jure harus dibuktikan lagi jika ada orang lain yang menyangkal hak tersebut ${ }^{19}$.

Dalam sistem pendaftaran hak cipta menurut perundang-undangan Hak Cipta Indonesia disebutkan bahwa pendaftaran ciptaan dilakukan secara pasif, artinya bahwa semua permohonan pendaftaran diterima dengan tidak terlalu mengadakan penelitian mengenai hak pemohon, kecuali sudah jelas ada pelanggaran hak cipta. Berdasarkan sikap pasif inilah membuktikan UUHC Indonesia menganut sistem deklaratif ${ }^{20}$.

17 J. C. T. Simorangkir dalam H. OK. Saidin, Aspek Hukum Hak Kekayaan Intelektual (Intellectual Property Rights) Cetakan Ke-4, Jakarta: PT. Raja Grafindo Persada, 2004, hlm. 91

18 Miriam Darus Badrulzaman, Mencari Sistem Hukum Benda Nasional, Bandung: BPHN-Alumni, 1983, hlm. 43

19 OK. Saidin, Op. Cit, hlm. 89

20 Ibid, hlm. 90

Siti Hatikasari, Esensi Perlindungan Hukum Dalam Sistem First To Announce Atas Karya Cipta 
Prosedur pendaftaran hak cipta dalam UUHC diatur pada Pasal 66 sampai dengan Pasal 73. Pencatatan diajukan dengan permohonan secara tertulis dalam bahasa Indonesia kepada Menteri dengan menyertakan contoh Ciptaan atau penggantinya, melampirkan surat pernyataan kepemilikan ciptaan dan membayar biaya. Menteri kemudian melakukan pemeriksaan terhadap permohonan yang telah memenuhi persyaratan dan hasil pemeriksaan digunakan sebagai bahan pertimbangan untuk menerima atau menolak permohonan. Apabila permohonan diterima, Menteri menerbitkan surat pencatatan ciptaan dan mencatat dalam daftar umum ciptaan. Sedangkan apabila permohonan ditolak, Menteri memberitahukan penolakan tersebut secara tertulis kepada Pemohon disertai alasan.

\section{Esensi Pendaftaran dalam Sistem First to Announce Dikaitkan Kasus dengan Putusan No. 08/ Pdt.Sus-Hak Cipta/2016/PN.Niaga.Jkt.Pst}

Hak cipta adalah suatu hak eksklusif atau khusus bagi pencipta. Hak ini tidak dimintakan kepada pemerintah, tetapi ketika seseorang mencipta harus diumumkan dan namanya dicantumkan pada ciptaan itu. Hal tersebut menyebabkan pencipta mempunyai hak eksklusif dengan sendirinya dan dilindungi oleh hukum, karena ketika tidak diumumkan maka pencipta tidak mendapatkan hak eksklusif. Hak eksklusif dalam hal ini adalah bahwa hanya pemegang hak bebas untuk menerapkan hak cipta, sementara orang atau pihak lain untuk melaksanakan hak cipta dilarang tanpa persetujuan dari pemegang hak cipta.

Menurut Ansori Sinungan, undang-undang hak cipta menganut prinsip bahwa pencipta mempunyai hak eksklusif untuk melaksanakan ciptaannya, artinya dalam kurun waktu tertentu pencipta mempunyai hak untuk melaksanakan sendiri ciptaannya atau memberi izin kepada orang lain untuk melaksanakan ciptaannya itu $^{21}$. Sehingga berdasarkan hal tersebut, maka pihak lain yang ingin ikut melaksanakan ciptaan dan mengambil manfaat ekonomi dari ciptaan tersebut harus mendapatkan izin dari pencipta yang bersangkutan.

Indonesia telah ikut serta dalam pergaulan masyarakat dunia dengan menjadi anggota dalam Agreement Establishing the World Trade Organization atau Persetujuan Pembentukan Organisasi Perdagangan Dunia yang mencakup pula Agreement on Trade Related Aspects of Intellectual Property Rights atau Persetujuan tentang Aspekaspek Dagang Hak Kekayaan Intelektual selanjutnya disebut TRIPS, melalui UU Nomor 7 Tahun 1994. Selain itu Indonesia juga meratifikasi Berne Convention for the Protection of Artistic and Literary Works atau Konvensi Berne tentang Perlindungan Karya Seni dan Sastra melalui Keputusan Presiden Nomor 18 Tahun 1997 dan World Intellectual Property Organization Copyrights Treaty atau Perjanjian Hak Cipta WIPO,

21 Ansori Sinungan, Pengertian Hak Cipta, cet. Ke-1, Jakarta: Departemen Hukum dan HAM RI, 2007, hlm. 1

Siti Hatikasari, Esensi Perlindungan Hukum Dalam Sistem First To Announce Atas Karya Cipta 
selanjutnya disebut WCT melalui Keputusan Presiden Nomor 19 Tahun $1997^{22}$. Perlindungan hak cipta merupakan salah satu tujuan dari diterbitkannya seluruh peraturan hukum tentang hak cipta, termasuk konvensi internasional tersebut di atas.

Perlindungan Hak Cipta di Indonesia diwujudkan dengan lahirnya peraturan perundang-undangan yang khusus mengatur tentang hak cipta. Indonesia telah beberapa kali mengubah peraturan perundang-undangan tentang hak cipta untuk menjamin kepastian hukum dan perlindungan terhadap pemegang hak cipta. Undang-Undang Nomor 28 Tahun 2014 tentang Hak Cipta (UUHC) merupakan undang-undang terbaru yang mengatur lingkup permasalahan di bidang hak cipta menggantikan undang-undang sebelumnya yaitu Undang-Undang Nomor 19 Tahun 2002. Adapun perlindungan yang diberikan oleh undang-undang terhadap hak cipta adalah untuk menghargai dan mendorong aktivitas para pencipta agar terus mencipta dan lebih kreatif. Lahirnya ciptaan baru atau ciptaan yang sudah ada sebelumnya harus didukung dan dilindungi oleh hukum. Wujud perlindungan itu dikukuhkan dalam undang-undang dengan menempatkan sanksi pidana terhadap orang-orang yang melanggar hak cipta dengan cara melawan hukum ${ }^{23}$.

Hal ini seperti terlihat pada kasus pembatalan pendaftaran ciptaan seni lukis motif abstrak berbentuk kepala orang dengan judul "Diesel Only The Brave" antara Diesel S.P.A. dengan Jemmy Wantono dengan Putusan Nomor 08/Pdt.Sus/Hak Cipta/2016/PN.Niaga.Jkt.Pst. Pada kasus ini Jemmy Wantono sebagai Tergugat melakukan pendaftaran atas ciptaan seni lukis motif abstrak berbentuk kepala orang dengan judul "Diesel Only The Brave" atas nama Tergugat yang diajukan pendaftarannya pertama kali pada tanggal 4 Oktober 1991, kemudian telah terdaftar dalam Daftar Umum Ciptaan yang terdapat di Kantor Hak Cipta (Direktorat Hak Cipta, Desain Industri, Desain Tata Letak Sirkuit Terpadu dan Rahasia Dagang, Ditjen HKI, Kementerian Hukum dan HAM RI, dan telah diumumkan untuk pertama kali pada tanggal 21 Februari 1985.

Diesel S.p.A. sebagai Penggugat mengajukan gugatan pembatalan pendaftaran ke Pengadilan Niaga Jakarta Pusat dengan alasan bahwa Penggugat adalah pemilik asli dari ciptaan seni lukis motif abstrak berbentuk kepala orang dengan judul "Diesel Only The Brave". Penggugat mengumumkan pertama kali ciptaan seni lukis "Diesel Only The Brave" pada tahun 1981 di Milan, Italia. Disamping digunakan sebagai Seni Lukis Logo, Penggugat juga telah menggunakannya sebagai merek dalam perdagangan barang dalam berbagai kelas jauh sebelum mendaftarkannya sebagai hak cipta. Penggugat mengajukan alasan bahwa terdapat kemiripan/kesamaan

22 Bambang Margono, Hak Cipta dan Keikutsertaan Indonesia, Jakarta: Media Indonesia Edisi 8 April 2008, hlm. 8

23 OK. Saidin, Op. Cit, hlm. 112

Siti Hatikasari, Esensi Perlindungan Hukum Dalam Sistem First To Announce Atas Karya Cipta 
hampir secara keseluruhan pada seni lukis yang didaftarkan Tergugat dengan ciptaan seni lukis "Diesel Only The Brave" milik Penggugat.

Majelis Hakim dalam pertimbangannya kemudian meminta bukti pendaftaran hak cipta seni lukis tersebut kepada Penggugat seperti yang telah didalilkan Penggugat sebelumnya untuk dibandingkan dengan bukti pendaftaran milik Tergugat, dan bukan hanya pada bukti pengumuman semata. Selain itu, dalam pertimbangannya Majelis Hakim juga menimbang bahwa sebagaimana perlindungan hukum karya cipta adalah bersifat otomatis, dengan pengertian bahwa suatu karya cipta mendapatkan perlindungan hukum sejak pertama kali dipublikasikan (first to announce) kepada masyarakat ${ }^{24}$. Sehingga dalam putusannya, Majelis Hakim memutuskan bahwa Penggugat adalah pemilik asli hak cipta seni lukis motif abstrak berbentuk kepala orang dengan judul "Diesel Only The Brave" dengan bukti pendaftaran hak cipta yang ditunjukkan oleh Penggugat dalam pengadilan serta bukti karya cipta tersebut telah diumumkan pertama kali (first to announce) oleh Penggugat pada tahun 1981 di Milan, Italia. Pendaftaran hak cipta atas nama Tergugat atas seni lukis dengan judul "Diesel Only The Brave" juga dibatalkan oleh Majelis Hakim karena terbukti melakukan pelanggaran Hak Cipta berdasarkan Undang-Undang Nomor 28 Tahun 2014 tentang Hak Cipta yaitu Tergugat telah mendaftarkan dan menggunakan hasil karya cipta orang lain tanpa mencantumkan Pencipta atau Pemegang Hak Ciptanya.

Berdasarkan kasus tersebut dapat dikatakan bahwa perlindungan hukum dalam hak cipta dapat dibuktikan dengan sistem yang mengumumkan pertama kali karya ciptanya (first to announce). First to announce pada hak cipta adalah hak untuk mengumumkan pertama kali hasil karyanya sendiri dan secara otomatis sebagai pemilik dari ciptaannya. Hal ini terbukti dalam pembuktian kasus antara Diesel S.p.A. melawan Jemmy Wantono dalam kasus pembatalan pendaftaran ciptaan seni lukis motif abstrak berbentuk kepala orang dengan judul "Diesel Only The Brave" yang telah didaftarkan oleh Jemmy Wantono yang mengaku sebagai pemilik hak cipta atas seni lukis tersebut. Diesel S.p.A. sebagai pemilik hak cipta atas seni lukis tersebut kemudian membuktikan dirinya pemilik asli ciptaan tersebut dengan menunjukkan bahwa yang pertama kali mengumumkan hasil karya cipta tersebut adalah Penggugat pada tahun 1981 di Milan, Italia, sedangkan Tergugat baru mengumumkan pertama kali ciptaan tersebut pada tahun 1985.

Walaupun Tergugat telah melakukan pendaftaran dengan dicatatkannya ciptaan seni lukis tersebut dalam Daftar Umum Ciptaan di Kantor Ditjen HKI atas nama Tergugat, namun dapat dibantah Penggugat dengan bukti first to announce yang dimiliki Penggugat. Hal ini disebabkan karena sejak pertama kali karya cipta diumumkan, maka secara otomatis hak cipta atas karya tersebut menjadi

24 Mahkamah Agung Republik Indonesia, Putusan No. 08/ Pdt.Sus-Hak Cipta/2016/PN.Niaga.Jkt.Pst, hlm. 31.

Siti Hatikasari, Esensi Perlindungan Hukum Dalam Sistem First To Announce Atas Karya Cipta 
kewenangan dari Pemilik atau Pemegang Hak Cipta. Sehingga dengan melekatnya hak cipta pada Pemilik atau Pemegang Hak Cipta sejak pertama kali diumumkan (first to announce) sehingga memberikan perlindungan hukum bagi Pemilik atau Pemegang Hak Cipta atas hasil karyanya. First to announce merupakan bentuk perlindungan yang lebih kuat dibandingkan pendaftaran atau pencatatan pada hak cipta, karena pendaftaran hak cipta tidak diharuskan, namun dapat digunakan sebagai pembuktia di pengadilan apabila terjadinya sengketa atau permasalahan seperti yang dapat dilihat pada kasus pembuktian di atas dimana Majelis Hakim meminta bukti berupa pendaftaran dari Penggugat selain bukti first to announce, untuk dibandingkan dengan bukti pendaftaran ciptaan yang dimiliki Tergugat.

\section{PENUTUP \\ Simpulan}

Berdasarkan Undang-Undang Nomor 28 Tahun 2014 tentang Hak Cipta (UUHC) disebutkan karya cipta yang dapat dilindungi yaitu karya cipta yang telah menjadi hak milik pribadi seseorang, sehingga dilarang melakukan penggandaan karya cipta atau menggunakan karya tanpa seizin Pemilik atau Pemegang Hak Cipta (Pasal 40), dan juga ada karya cipta yang tidak dilindungi (Pasal 41). Pada prinsipnya hak cipta diperoleh bukan karena pendaftaran, sehingga tidak ada keharusan bagi Pencipta untuk mendaftarkan ciptaannya seperti disebutkan pada Pasal 64 ayat (2) UUHC bahwa pencatatan bukan syarat untuk mendapatkan Hak Cipta dan Hak Terkait, namun apabila terjadi sengketa di pengadilan mengenai ciptaan yang terdaftar dan yang tidak terdaftar, hakim dapat menentukan pencipta yang sebenarnya berdasarkan pembuktian tersebut. Sehingga pendaftaran atau pencatatan merupakan salah satu bentuk perlindungan hukum hak cipta selain pengumuman pertama kali hasil karya cipta, walaupun pendaftaran hak cipta bukan merupakan suatu keharusan. Pendaftaran hak cipta di Indonesia menggunakan sistem pendaftaran dekalaratis dan dalam UUHC prosedur pendaftaran tersebut diatur pada Pasal 66 sampai dengan Pasal 73. Oleh karena itu ketentuan tersebutlah yang menjadi pertimbangan hakim terkait first to announce dalam pembuktian kasus antara Diesel S.p.A. melawan Jemmy Wantono dalam kasus pembatalan pendaftaran ciptaan seni lukis motif abstrak berbentuk kepala orang dengan judul "Diesel Only The Brave".

\section{DAFTAR PUSTAKA}

Badrulzaman, Miriam Darus. 1983, Mencari Sistem Hukum Benda Nasional, Bandung: BPHN-Alumni.

Boer, Muhammad Riyan Kachfi, 2015, Tinjauan Yuridis Tentang Tindak Pidana Terhadap Hak Cipta Atas Perangkat Lunak Komputer (Studi Kasus Putusan

Siti Hatikasari, Esensi Perlindungan Hukum Dalam Sistem First To Announce Atas Karya Cipta 
Nomor 2277 K/Pid/2006), dalam Skripsi Fakultas Hukum Universtas Hasanuddin.

Djaja, Hendra. 2010, Hukum Hak Kekayaan Intelektual, Malang: Surya Pena Gemilang.

Hasibuan, Aryani Nauli, 2011, Perlindungan Hak Cipta Atas Karya Derivatif dalam Prakteknya: Studi Kasus Buku Ensiklopedia Al-Quran: Al-Maushuah AlQuraniyah Al-Muyassarah, dalam Tesis Fakultas Hukum Universitas Indonesia.

Hutahuruk, M. 1982, Peraturan Hak Cipta Nasional, Jakarta: Erlangga.

Mahadewi, Kadek Julia, 2015. Budaya Hukum Dalam Keberlakuan Undang-Undang Nomor 28 Tahun 2014 Tentang Hak Cipta Pada Pengrajin Perak di Bali. Jurnal Magister Hukum Udayana, 4 (2), 205-218. doi: 10.24843/JMHU.2015.v04.i02. p.206

Margono, Bambang, 2008, Hak Cipta dan Keikutsertaan Indonesia, Jakarta: Media Indonesia Edisi 8 April 2008.

Purwaningsih, Endang, 2005, Perkembangan Hukum Intellectual Property Rights, Jakarta: Ghalia Indonesia.

Rafianti, Laina, 2018. Resensi Buku: Sejarah dan Politik Hukum Hak Cipta. Jurnal Bina Mulia Hukum, 2(2), 266-273. doi : 10.23920/jbmh.v2n2.21. p.269-270

Republik Indonesia, Undang-Undang Nomor 28 Tahun 2014 tentang Hak Cipta, Lembaran Negara Republik Indonesia (LNRI) Tahun 2014 Nomor 266, dan Tambahan Lembaran Negara (TLM) Nomor 5599.

---------------, Mahkamah Agung, Putusan Nomor 08/Pdt.Sus-Hak Cipta/2016/PN.Niaga.Jkt.Pst.

Saidi, OK. 2004, Aspek Hukum Hak Kekayaan Intelektual (Intellectual Property Rights) Cetakan Ke-4, Jakarta: PT. Raja Grafindo Persada.

Soekanto, Soerjono., dan Sri Mamudji. 2012, Penelitian Hukum Normatif, Jakarta: PT. Raja Grafindo Persada.

Siti Hatikasari, Esensi Perlindungan Hukum Dalam Sistem First To Announce Atas Karya Cipta 
Soelistyo, Henry, 2011, Hak Cipta Tanpa Hak Moral, Jakarta: PT. Raja Grafindo Persada.

Yanto, Oksidelfa, (2015). Konsep Perlindungan hak Cipta Karya Musik Dalam ranah Hukium Hak Kekayaan Intelektual dari Tindak Pidana Pembajakan. Jurnal Cita Hukum, 3(1), 99-114, 2015. doi: 10.15408/JCH.v2i1.2310.2015.3.1.p.100

Siti Hatikasari, Esensi Perlindungan Hukum Dalam Sistem First To Announce Atas Karya Cipta 